\title{
Funding of German Lander, Mechanisms and
}

\section{Solidarity}

\author{
Julien Vandernoot ${ }^{1, *}$
}

${ }^{1}$ Public Finance and Tax department, Warocqué School of Business and Economics, University of Mons (UMONS), Belgium

*Correspondence: Place Warocqué, 17, 7000 Mons, Belgium.

E-mail: Julien.Vandernoot@umons.ac.be

Received: March 6, $2014 \quad$ Accepted: March 20, $2014 \quad$ Published: April 7, 2014

doi:10.5296/rae.v6i2.5252ＵRL: http://dx.doi.org/10.5296/rae.v6i2.5252

\begin{abstract}
Germany is a federal state made up of 16 constituent states, called Länder. Considering the country's history of division between West and East and the wealth gap which is still much alive between the two regions, German authorities have decided to put in place solidarity mechanisms in order to restore some balance.

The purpose of this article is to gain an understanding of all these mechanisms and assess their impact, based on the rules and formula provided by the German law and on calculations for the year 2010. This article clearly highlights the very redistributive character of the German system and even reveals a paradox of revenues, leading to the poorest Länder becoming some of the wealthiest and vice versa.
\end{abstract}

Keywords: equalization, federalism, paradox of revenue, solidarity, funding of federated entities, Germany, Länder 


\section{Mll Macrothink}

Research in Applied Economics

ISSN 1948-5433

2014, Vol. 6, No. 2

\section{Introduction(Note 1)}

Germany is made up of sixteen Länder, namely: Baden-Württemberg, Bavaria, Berlin, Brandenburg, Bremen, Hamburg, Hesse, Lower Saxony, Mecklenburg-Vorpommern, North Rhine-Westphalia, Rhineland-Palatinate, Saarland, Saxony, Saxony-Anhalt, SchleswigHolstein and Thuringia.

Some of these (Note 2) are located on the territory of the former Federal Republic of Germany (FRG or West Germany) and others(Note 3) on the territory of the former German Democratic Republic (GDR or East Germany). Berlin used to be divided into East and West Berlin (West Berlin being part of West Germany and East Berlin being part of East Germany).

Three of the current Länder are city-states, composed of one (Berlin and Hamburg) or two disctricts (Bremen).

Today’s Federal Republic of Germany was created in 1990 from the unification of all these Länder.

The distinction between west and eastern Länder is important, considering the still great disparity of wealth between the two regions, which gives rise to an appropriate funding of the latters.

The funding of the Länder is not frequently studied in scientific literature. The former funding mechanisms, which took place before the reform of 2001, have nevertheless been evoked by Gunlicks (2003) and Spahn and Werner (2007).

This article will first examine the current funding mechanisms of the Länder and place figures on the amounts they received.

It will then measure the solidarity by calculating the difference between the amounts the Länder have received and the ones the Länder would have received in the absence of redistributive mechanisms.

These elements will highlight the degree of solidarity in the funding system of the German Länder and will identify the contributors and the beneficiaries.

\section{Funding Mechanisms}

The latest major amendment to the funding mechanisms of German Länder was voted in 2001 and entered into force in 2005, following a German Constitutional Court (Bundesverfassungsgericht) decision of 1999(Note 4) requiring modifications of the mechanisms in force until then.

The financial equalization law between the federal state and the Länder (Finanzausgleichsgesetz) (Note 5) was born.

The decision of the German Constitutional Court came in response to an appeal brought by 
the Länder of Baden-Württemberg, Bavaria and Hesse, which are major funding contributors.

Today’s funding mechanism of the German Länder includes four stages, namely:

- Distribution of the value added tax, the corporate tax and the income tax between the federal state, the Länder and the municipalities;

- Distribution of the value added tax between the Länder;

- Horizontal equalization;

- Federal grants.

It should also be noted that the financial equalization law currently in force will in principle remain in place until 2019, when some of the funding mechanisms it provides are due to expire. We use the words "in principle”, because the Länder of Bavaria and Hesse filed a new appeal against the current equalization system to the Constitutional Court in 2013. (Note 6)

2.1 Distribution of the value added tax, the corporate tax and the income tax between the federal state, the Länder and the municipalities

In 2010, the corporate tax was equally distributed between the federal State and the Länder ( $50 \%$ for each part). The share allocated to the Länder is then divided depending on the Land of domicile of each company(Note 7).

$42.5 \%$ of the income tax is awarded to the federal state, $42.5 \%$ to the Länder and $15 \%$ to the municipalities. The criterion of residence applies to the allocation of the Länder's share.

The distribution of the value added tax (VAT) is more complex. The financial equalization law between the federal state and the Länder (Finanzausgleichsgesetz) indeed provides that 9.5\% of the VAT receipts are first attributed to the federal state, among other things as a form of compensation for the increase in pension payments made by the State. In addition, $2.2 \%$ of the VAT is allocated to the municipalities. The amount that is left is then divided between the federal state (50.5\%) and the Länder (49.5\%).

\subsection{Distribution of the value added tax between the Länder}

Section 2 of the financial equalization law between the federal state and the Länder provides a set of rules applicable to the distribution of VAT between the Länder.

The share attributed to the Länder is divided into two parts: the first one amounts to a maximum of a quarter of the total and the second is equal to the balance.

The first part is shared between the Länder whose revenues from income tax, corporate tax and Länder tax are below the average (which was of 1309.23 euro per inhabitant in 2010(Note 8)).

Each of these Länder receives what is called an additional share (ergänzungsanteile).

i. The Länder whose aforementioned revenues are lower than $97 \%$ of the average receive an amount calculated according to the following formula: 


$$
S_{L}=R_{A} \times P_{L} \times\left(\left(\frac{19}{20} \times\left(1-\frac{R I_{L}}{100}\right)\right)-\frac{21}{4000}\right)
$$

$\mathrm{S}_{\mathrm{L}}=$ additional share allocated to the Land in question

$\mathrm{R}_{\mathrm{A}}=$ average revenues per inhabitant for all Länder from the income tax, the corporate tax and Länder tax.

$\mathrm{P}_{\mathrm{L}}=$ the number of inhabitants in the Land in question

$\mathrm{RI}_{\mathrm{L}}=$ the revenues index of the Land (average: 100)

ii. The Länder whose aforementioned revenues are between $97 \%$ and $100 \%$ of the average receive an amount calculated according to the following formula:

$$
S_{L}=R_{A} \times P_{L} \times\left(\left(\frac{1-R I_{L}}{100}\right)\left(\frac{35}{6} \times\left(\frac{1-R I_{L}}{100}\right)\right)+\frac{3}{5}\right)
$$

$\mathrm{S}_{\mathrm{L}}=$ additional Share allocated to the Land in question

$\mathrm{R}_{\mathrm{A}}=$ average revenues per inhabitant for all Länder from the income tax, the corporate tax and Länder tax.

$\mathrm{P}_{\mathrm{L}}=$ the number of inhabitants in the Land in question

$\mathrm{RI}_{\mathrm{L}}=$ the revenues index of the Land (average: 100)

A verification is then made to ensure that the total amount allocated as additional shares (ergänzungsanteile) does not exceeds $25 \%$ of the share of VAT receipts attributed to the Länder. No such problem occurred in 2010, the ergänzungsanteile amounting to $12.52 \%$ of the Länder share of VAT receipts (10 092047000 euro out of 80587873000 euro) (Note 9).

If the authorized thresholds are exceeded, the financial equalization law between the federal state and the Länder provides that the allocated amounts in question shall be reduced proportionally.

The rest of the Länder share of VAT receipts (70 495826000 euro in 2010, that is $87.48 \%$ of the total) is then shared out proportionately to the population of the Länder.

The amounts received by the Länder as additional shares (Ergänzungsanteile) and as part of the proportional distribution of the VAT are shown in e.g. Table 1. 


\section{Ml Macrothink}

Research in Applied Economics

ISSN 1948-5433

Table 1. Amounts received by the Länder as additional shares (Ergänzungsanteile) and as part of the proportional distribution of the VAT

\begin{tabular}{|c|c|c|c|c|c|c|c|c|}
\hline \multirow{2}{*}{ Land } & \multicolumn{5}{|l|}{ Ergänzungsanteile } & \multicolumn{2}{|c|}{$\begin{array}{l}\text { Distribution proportional to the } \\
\text { population }\end{array}$} & \multirow{2}{*}{$\begin{array}{l}\text { Total allocated } \\
\text { amount } \quad(* 1000 \\
\text { euro })\end{array}$} \\
\hline & $\begin{array}{l}\text { Revenues }(* 1000 \\
\text { euro) }\end{array}$ & $\begin{array}{l}\text { Revenues per } \\
\text { inhabitant (euro) }\end{array}$ & $\begin{array}{l}\text { Revenues index } \\
\text { per inhabitant } \\
\text { (average }=100 \text { ) }\end{array}$ & $\begin{array}{l}\text { entitlement to the } \\
\text { ergänzungsanteile } \\
\text { (YES/NO) }\end{array}$ & $\begin{array}{l}\text { Allocated } \\
\text { amount } \quad(* 1000 \\
\text { euro })\end{array}$ & Population & $\begin{array}{l}\text { Allocated } \\
\text { amount } \\
(* 1000 \text { euro })\end{array}$ & \\
\hline North Rhine-Westphalia & 23488028 & 1315.81 & 100.50 & NO & 0 & 17850560 & 15393014 & 15393014 \\
\hline Bavaria & 21197350 & 1693.20 & 129.33 & NO & 0 & 12519130 & 10795580 & 10795580 \\
\hline Baden-Württemberg & 16495969 & 1534.52 & 117.21 & NO & 0 & 10749924 & 9269946 & 9269946 \\
\hline Lower Saxony & 8898695 & 1121.83 & 85.69 & YES & 1357667 & 7932282 & 6840219 & 8197886 \\
\hline Hesse & 10114447 & 1667.98 & 127.40 & NO & 0 & 6063885 & 5229050 & 5229050 \\
\hline Saxony & 2737375 & 659.03 & 50.34 & YES & 2537114 & 4153631 & 3581787 & 6118901 \\
\hline Rhineland-Palatinate & 5111201 & 1275.57 & 97.43 & YES & 101167 & 4006995 & 3455339 & 3556506 \\
\hline Saxony-Anhalt & 1483533 & 632.72 & 48.33 & YES & 1490773 & 2344679 & 2021879 & 3512652 \\
\hline Schleswig-Holstein & 3461707 & 1222.63 & 93.39 & YES & 213488 & 2831364 & 2441561 & 2655049 \\
\hline Thuringia & 1427639 & 637.01 & 48.66 & YES & 1415827 & 2241157 & 1932610 & 3348437 \\
\hline Brandenburg & 2030142 & 809.58 & 61.84 & YES & 1173078 & 2507654 & 2162417 & 3335495 \\
\hline Mecklenburg-Vorpommern & 1056519 & 641.66 & 49.01 & YES & 1032909 & 1646539 & 1419855 & 2452764 \\
\hline Saarland & 1063211 & 1042.55 & 79.63 & YES & 251357 & 1019815 & 879414 & 1130771 \\
\hline Berlin & 3976339 & 1154.44 & 88.18 & YES & 482851 & 3444400 & 2970198 & 3453049 \\
\hline Hamburg & 3667583 & 2061.44 & 157.45 & NO & 0 & 1779140 & 1534200 & 1534200 \\
\hline Bremen & 821046 & 1244.84 & 95.08 & YES & 35816 & 659561 & 568757 & 604573 \\
\hline Total & 107030784 & & & & 10092047 & 81750716 & 70495826 & 80587873 \\
\hline Average & & 1309.23 & 100.00 & & & & & \\
\hline
\end{tabular}

Sources: Second order of Germany's federal finance Minister with a view to implementing the financial equalization law of 2010, own calculations.

\subsection{Horizontal equalization}

Equalization is provided for under article 107 of the German Constitution(Note 10), which establishes the principle of it.

The implementation of equalization is however provided for by the financial equalization law between the federal state and the Länder (Finanzausgleichsgesetz), which states that the Länder whose financial strength index is lower than the equalization index shall receive a contribution financed by the Länder whose financial strength index is higher than the equalization index.

These two indexes are calculated according to the following formulae:

$$
F S I_{L}=R_{L}+\left(0.64 \times R_{M}\right)
$$

$\mathrm{FSI}_{\mathrm{L}}=$ financial strength index of the Land in question

$\mathrm{R}_{\mathrm{L}}=$ revenues of the Land from the income tax, the corporate tax, the Länder taxes, the value added tax and royalties.

$\mathrm{R}_{\mathrm{M}}=$ revenues of the municipalities in the Land in question and

$$
E I_{L}=\left(\frac{R_{T} \times P_{L} \times C_{L 1}}{W P_{T 1}}\right)+\left(0.64 \times\left(\frac{R_{M T} \times P_{L} \times C_{L 2}}{W P_{T 2}}\right)\right)
$$


$\mathrm{EI}_{\mathrm{L}}=$ equalization index of the Land in question

$\mathrm{R}_{\mathrm{T}}=$ total revenues of all Länder from the income tax, the corporate tax, the Länder taxes, the value added tax and royalties

$\mathrm{P}_{\mathrm{L}}=$ population in the Land in question

$\mathrm{C}_{\mathrm{L} 1}=$ population coefficient assigned to the Land in question for the first part of the formula(Note 11)

$\mathrm{WP}_{\mathrm{T} 1}=$ total German population weighted to reflect the population coefficients assigned to the Länder for the first part of the formula (in 2010: 83809801.35 inhabitants) (Note 12)

$\mathrm{R}_{\mathrm{MT}}=$ total municipal revenues for all the Länder

$\mathrm{C}_{\mathrm{L} 2}=$ population coefficient assigned to the Land in question for the second part of the formula(Note 13)

$\mathrm{WP}_{\mathrm{T} 2}=$ total German population weighted to reflect the population coefficients assigned to the Länder for the second part of the formula (in 2010: 84014251.5 inhabitants) (Note 14)

i. Länder whose financial strength index is lower than $80 \%$ of the equalization index receive an equalization amount calculated according to the following formula:

$$
E A_{L}=E I_{L} \times\left(\left(\frac{3}{4} \times\left(1-\frac{F S I_{L}}{E I_{L}}\right)\right)-\frac{317}{20000}\right)
$$

$\mathrm{EA}_{\mathrm{L}}=$ equalization amount allocated to the Land in question

$\mathrm{EI}_{\mathrm{L}}=$ equalization index of the Land in question

$\mathrm{FSI}_{\mathrm{L}}=$ financial strength index of the Land in question

ii. Länder whose financial strength index is greater than or equal to $80 \%$ of the equalization index, but lower than $93 \%$ of it, receive an equalization amount calculated according to the following formula:

$$
E A_{L}=E I_{L} \times\left(1-\frac{F S I_{L}}{E I_{L}}\right) \times\left(\left(\frac{5}{26} \times\left(1-\frac{F S I_{L}}{E I_{L}}\right)+\frac{35}{52}\right)-\frac{2121}{260000}\right)
$$

$\mathrm{EA}_{\mathrm{L}}=$ equalization amount allocated to the Land in question

$\mathrm{EI}_{\mathrm{L}}=$ equalization index of the Land in question

$\mathrm{FSI}_{\mathrm{L}}=$ financial strength index of the Land in question

iii. Länder whose financial strength index is greater than or equal to $93 \%$ of the equalization index, but lower than $100 \%$ of it, receive an equalization amount calculated according to the following formula:

$$
E A_{L}=E I_{L} \times\left(1-\frac{F S I_{L}}{E I_{L}}\right) \times\left(\frac{13}{7} \times\left(1-\frac{F S I_{L}}{E I_{L}}\right)+\frac{11}{25}\right)
$$


$\mathrm{EA}_{\mathrm{L}}=$ equalization amount allocated to the Land in question

$\mathrm{EI}_{\mathrm{L}}=$ equalization index of the Land in question

$\mathrm{FSI}_{\mathrm{L}}=$ financial strength index of the Land in question

Conversely, Länder whose financial strength index is greater than the equalization index contribute to the equalization.

iv. Länder whose financial strength index is greater than the equalization index, but lower than $107 \%$ of it, pay an equalization amount calculated according to the following formula:

$$
A P_{L}=A C \times E I_{L} \times\left(\frac{F S I_{L}}{E I_{L}}-1\right) \times\left(\frac{13}{7} \times\left(\frac{F S I_{L}}{E I_{L}}-1\right)+\frac{11}{25}\right)
$$

$\mathrm{AP}_{\mathrm{L}}=$ equalization amount paid by the Land in question

AC = adjustment coefficient applied in order to match the total amount received as equalization allocations with the total amount paid as equalization contributions, which is calculated according to the following formula:

\section{Total amount received by the Länder benefiting from equalization}

Total amount paid by the Länder supporting equalization

This coefficient was of 0.9901 in 2010.

$\mathrm{EI}_{\mathrm{L}}=$ equalization index of the Land in question

$\mathrm{FSI}_{\mathrm{L}}=$ financial strength index of the Land in question

v. Länder whose financial strength index is greater than or equal to $107 \%$ of the equalization index, but lower than $120 \%$ of it, pay an equalization amount calculated according to the following formula:

$$
A P_{L}=A C \times E I_{L} \times\left(\frac{F I_{L}}{E I_{L}}-1\right) \times\left(\left(\frac{5}{26} \times\left(\frac{F I_{L}}{E I_{L}}-1\right)+\frac{35}{52}\right)-\frac{2121}{260000}\right)
$$

$\mathrm{AP}_{\mathrm{L}}=$ equalization amount paid by the Land in question

AC $=$ adjustment coefficient applied in order to match the total amount received as equalization allocations with the total amount paid as equalization contributions, which is calculated according to the following formula:

Total amount received by the Länder benefiting from equalization

Total amount paid by the Länder supporting equalization

This coefficient was of 0.9901 in 2010.

$\mathrm{EI}_{\mathrm{L}}=$ equalization index of the Land in question

$\mathrm{FSI}_{\mathrm{L}}=$ financial strength index of the Land in question 
vi. And Länder whose financial strength index is greater than or equal to $120 \%$ of the equalization index pay an equalization amount calculated according to the following formula:

$$
A P_{L}=A C \times E I_{L} \times\left(\frac{3}{4} \times\left(\frac{F S I_{L}}{E I_{L}}-1\right)-\frac{317}{20000}\right)
$$

$\mathrm{AP}_{\mathrm{L}}=$ equalization amount paid by the Land in question

AC = adjustment coefficient applied in order to match the total amount received as equalization allocations with the total amount paid as equalization contributions, which is calculated according to the following formula:

\section{Total amount received by the Länder benefiting from equalization Total amount paid by the Länder supporting equalization}

This coefficient was of 0.9901 in 2010.

$\mathrm{EI}_{\mathrm{L}}=$ equalization index of the Land in question

$\mathrm{FSI}_{\mathrm{L}}=$ financial strength index of the Land in question

The amounts received or paid by the Länder as a form of equalization are shown in Table 2 below.

Table 2. Amounts received or paid as a form of equalization in Germany (2010)

\begin{tabular}{|c|c|c|c|c|c|c|c|c|c|}
\hline \multirow[t]{2}{*}{ Land } & \multicolumn{3}{|c|}{$\begin{array}{l}\text { Financial strength index (FSI) } \\
\text { (thousand euro) (municipal indexes are } \\
\text { multiplied by 0.64) }\end{array}$} & \multicolumn{3}{|c|}{$\begin{array}{c}\text { Equalization index (EI) (thousand euro) } \\
\text { (municipal indexes are multiplied by } 0.64 \text { ) }\end{array}$} & \multirow[t]{2}{*}{ FSI/EI*100 } & \multirow{2}{*}{$\begin{array}{l}\text { Land: contributor or } \\
\text { beneficiary? }\end{array}$} & \multirow[t]{2}{*}{$\begin{array}{l}\text { Amount received } \\
(+) \text { or paid }(-) \\
\text { (thousand euro) }\end{array}$} \\
\hline & Municipalities & Länder & Total & Municipalities & Länder & Total & & & \\
\hline North Rhine-Westphalia & 10265897 & 38881529 & 49147426 & 9847576 & 40056639 & 49904215 & 98.48 & beneficiary & 354301 \\
\hline Bavaria & 8456335 & 31993370 & 40449705 & 6906399 & 28092915 & 34999314 & 115.57 & contributor & -3511134 \\
\hline Baden-Württemberg & 7181884 & 25722512 & 32904396 & 5930385 & 24122819 & 30053204 & 109.49 & contributor & -1708837 \\
\hline Lower Saxony & 4040280 & 17601267 & 21641547 & 4375983 & 17800033 & 22176016 & 97.59 & beneficiary & 259089 \\
\hline Hesse & 4319577 & 15344125 & 19663702 & 3345249 & 13607352 & 16952601 & 115.99 & contributor & -1752340 \\
\hline Saxony & 1413210 & 8835344 & 10248554 & 2291424 & 9320744 & 11612168 & 88.26 & beneficiary & 853882 \\
\hline Rhineland-Palatinate & 2022122 & 8671563 & 10693685 & 2210529 & 8991693 & 11202222 & 95.46 & beneficiary & 266630 \\
\hline Saxony-Anhalt & 798436 & 4991343 & 5789779 & 1319353 & 5261457 & 6580810 & 87.98 & beneficiary & 497026 \\
\hline Schleswig-Holstein & 1509717 & 6198675 & 7708392 & 1561972 & 6353578 & 7915550 & 97.38 & beneficiary & 101218 \\
\hline Thuringia & 739627 & 4774149 & 5513776 & 1236374 & 5029154 & 6265528 & 88.00 & beneficiary & 472220 \\
\hline Brandenburg & 1022210 & 5366385 & 6388595 & 1424893 & 5627173 & 7052066 & 90.59 & beneficiary & 401042 \\
\hline Mecklenburg-Vorpommern & 516823 & 3506440 & 4023263 & 953759 & 3694832 & 4648591 & 86.55 & beneficiary & 399149 \\
\hline Saarland & 493615 & 2193982 & 2687597 & 562599 & 2288464 & 2851063 & 94.27 & beneficiary & 89331 \\
\hline Berlin & 1495573 & 7362764 & 8858337 & 2565221 & 10434461 & 12999682 & 68.14 & beneficiary & 2899964 \\
\hline Hamburg & 1654598 & 5200044 & 6854642 & 1325017 & 5389724 & 6714741 & 102.08 & contributor & -66307 \\
\hline Bremen & 418037 & 1425619 & 1843656 & 491209 & 1998073 & 2489282 & 74.06 & beneficiary & 444764 \\
\hline Total & 46347942 & 188069111 & 234417053 & 46347942 & 188069111 & 234417053 & & & 0 \\
\hline
\end{tabular}

Sources: Second order of Germany's federal finance Minister with a view to implementing the financial equalization law of 2010.

\subsection{Federal grants(Note 15)}

Two different kinds of federal additional grants (Bundesergänzungszuweisungen) are made to the Länder. 
On the one hand, general federal additional grants are attributed to Länder whose financial strength index and horizontal equalization compensations combined are lower than $99.5 \%$ of the equalization index. These Länder receive $77.5 \%$ of the difference.

The amounts received by the Länder as general federal additional grants are shown in e.g. table 3 .

Table 3. Amounts received by the Länder as general federal additional grants (2010)

\begin{tabular}{|c|c|c|c|c|}
\hline Land & $\begin{array}{c}\text { Financial } \\
\text { strength capacity } \\
+ \text { equalization } \\
\text { (FSI + E) } \\
\text { (thousand euro) }\end{array}$ & $\begin{array}{l}\text { Equalization } \\
\text { index (EI) } \\
\text { (thousand } \\
\text { euro) }\end{array}$ & $\begin{array}{c}(\mathrm{FSI}+ \\
\mathrm{E}) /(\mathrm{EI})^{*} 100\end{array}$ & $\begin{array}{l}\text { Amount } \\
\text { received } \\
\text { (thousand } \\
\text { euro) }\end{array}$ \\
\hline North Rhine-Westphalia & 49501727 & 49904215 & 99.193 & 118549 \\
\hline Bavaria & 36938571 & 34999314 & 105.541 & 0 \\
\hline Baden-Württemberg & 31195559 & 30053204 & 103.801 & 0 \\
\hline Lower Saxony & 21900636 & 22176016 & 98.758 & 127487 \\
\hline Hesse & 17911362 & 16952601 & 105.656 & 0 \\
\hline Saxony & 11102436 & 11612168 & 95.610 & 350045 \\
\hline Rhineland-Palatinate & 10960315 & 11202222 & 97.841 & 144069 \\
\hline Saxony-Anhalt & 6286805 & 6580810 & 95.532 & 202353 \\
\hline Schleswig-Holstein & 7809610 & 7915550 & 98.662 & 51431 \\
\hline Thuringia & 5985996 & 6265528 & 95.539 & 192358 \\
\hline Brandenburg & 6789637 & 7052066 & 96.279 & 176056 \\
\hline Mecklenburg-Vorpommern & 4422412 & 4648591 & 95.134 & 157275 \\
\hline Saarland & 2776928 & 2851063 & 97.399 & 46407 \\
\hline Berlin & 11758301 & 12999682 & 90.451 & 911697 \\
\hline Hamburg & 6788335 & 6714741 & 101.096 & 0 \\
\hline Bremen & 2288420 & 2489282 & 91.931 & 146022 \\
\hline Total & & & & 2623750 \\
\hline
\end{tabular}

Sources: second order of Germany's federal finance Minister with a view to implementing the financial equalization law of 2010, own calculations.

On the other hand, exceptional federal additional grants (SonderbedarfsBundesergänzungszuweisungen) are attributed to Länder sustaining different kinds of burdens. Three categories of exceptional federal grants can be distinguished.

The first one aims to compensate for the backwardness with regard to infrastructures and for the low financial strength of municipalities in the five eastern Länder and in the city-state of Berlin. To this end, they have received 8.743 billion euro in 2010 according to an allocation key provided for by the financial equalization law between the federal state and the Länder. [This amount has been decreasing from year to year since 2005 and will continue to do so until 2019, when the measure is due to expire in accordance with the financial equalization law between the federal state and the Länder.] 


\section{Macrothink

The second one provides the five eastern Länder with an amount intended to cover the costs associated with high unemployment and resulting high social charges. One billion euro has been allocated to this purpose in 2010, according to an allocation key provided for by the financial equalization law between the federal state and the Länder.

And the last one is designed to support ten small Länder that have to bear higher political management costs. 516.9 billion euro have been paid as such in 2010 .

The amounts received by the Länder as exceptional federal additional grants are shown in e.g. table 4.

Table 4. Amounts received by the Länder as exceptional federal additional grants (2010)

\begin{tabular}{lccc}
\hline \multicolumn{1}{c}{ Land } & $\begin{array}{c}\text { First grant } \\
\text { (thousand euro) }\end{array}$ & $\begin{array}{c}\text { Second grant } \\
\text { (thousand euro) }\end{array}$ & $\begin{array}{c}\text { Third grant } \\
\text { (thousand euro) }\end{array}$ \\
\hline North Rhine-Westphalia & 0 & 0 & 0 \\
Bavaria & 0 & 0 & 0 \\
Baden-Württemberg & 0 & 0 & 0 \\
Lower Saxony & 0 & 0 & 0 \\
Hesse & 0 & 0 & 0 \\
Saxony & 2279803 & 319000 & 25565 \\
Rhineland-Palatinate & 0 & 0 & 46016 \\
Saxony-Anhalt & 1375569 & 187000 & 52663 \\
Schleswig-Holstein & 0 & 0 & 53174 \\
Thuringia & 1250910 & 176000 & 55731 \\
Brandenburg & 1252615 & 190000 & 55220 \\
Mecklenburg-Vorpommern & 921205 & 128000 & 61355 \\
Saarland & 0 & 0 & 63400 \\
Berlin & 1662989 & 0 & 43460 \\
Hamburg & 0 & 0 & 0 \\
Bremen & 0 & 0 & 60332 \\
Total & 8743091 & 1000000 & 516916 \\
\hline
\end{tabular}

Sources: Financial equalization law between the federal state and the Länder, own calculations.

\section{Summary}

Table 5 below summarizes the amounts allocated to each Land in the framework of the different funding mechanisms provided for by the German law. 


\section{I Macrothink}

Research in Applied Economics

ISSN 1948-5433

2014, Vol. 6, No. 2

Table 5. Amounts allocated to the Länder in the framework of the funding mechanisms provided for by the German law (2010, thousand euro)

\begin{tabular}{|c|c|c|c|c|c|c|c|c|c|}
\hline \multirow{2}{*}{ Land } & \multicolumn{3}{|c|}{ VAT } & \multirow{2}{*}{ Equalization } & \multirow{2}{*}{$\begin{array}{c}\text { General federal } \\
\text { grants } \\
\end{array}$} & \multicolumn{4}{|c|}{ Exceptional federal grants } \\
\hline & Ergänzungsanteile & Population & Total & & & Grant 1 & Grant 2 & Grant 3 & Total \\
\hline North Rhine-Westphalia & 0 & 15393014 & 15393014 & 354301 & 118549 & 0 & 0 & 0 & 0 \\
\hline Bavaria & 0 & 10795580 & 10795580 & -3511134 & 0 & 0 & 0 & 0 & 0 \\
\hline Baden-Württemberg & 0 & 9269946 & 9269946 & -1708837 & 0 & 0 & 0 & 0 & 0 \\
\hline Lower Saxony & 1357667 & 6840219 & 8197886 & 259089 & 127487 & 0 & 0 & 0 & 0 \\
\hline Hesse & 0 & 5229050 & 5229050 & -1752340 & 0 & 0 & 0 & 0 & 0 \\
\hline Saxony & 2537114 & 3581787 & 6118901 & 853882 & 350045 & 2279803 & 319000 & 25565 & 2624368 \\
\hline Rhineland-Palatinate & 101167 & 3455339 & 3556506 & 266630 & 144069 & 0 & 0 & 46016 & 46016 \\
\hline Saxony-Anhalt & 1490773 & 2021879 & 3512652 & 497026 & 202353 & 1375569 & 187000 & 52663 & 1615232 \\
\hline Schleswig-Holstein & 213488 & 2441561 & 2655049 & 101218 & 51431 & 0 & 0 & 53174 & 53174 \\
\hline Thuringia & 1415827 & 1932610 & 3348437 & 472220 & 192358 & 1250910 & 176000 & 55731 & 1482641 \\
\hline Brandenburg & 1173078 & 2162417 & 3335495 & 401042 & 176056 & 1252615 & 190000 & 55220 & 1497835 \\
\hline Mecklenburg-Vorpommern & 1032909 & 1419855 & 2452764 & 399149 & 157275 & 921205 & 128000 & 61355 & 1110560 \\
\hline Saarland & 251357 & 879414 & 1130771 & 89331 & 46407 & 0 & 0 & 63400 & 63400 \\
\hline Berlin & 482851 & 2970198 & 3453049 & 2899964 & 911697 & 1662989 & 0 & 43460 & 1706449 \\
\hline Hamburg & 0 & 1534200 & 1534200 & -66307 & 0 & 0 & 0 & 0 & 0 \\
\hline Bremen & 35816 & 568757 & 604573 & 444764 & 146022 & 0 & 0 & 60332 & 60332 \\
\hline Total & 10092047 & 70495826 & 80587873 & 0 & 2623750 & 8743091 & 1000000 & 516916 & 10260007 \\
\hline
\end{tabular}

Sources: Second order of Germany's federal finance Minister with a view to implementing the financial equalization law of 2010, financial equalization law between the federal state and the Länder, own calculations.

\section{Solidarity}

Table 6 below describes the changes in the financial position of Länder as the funding mechanisms are gradually being introduced.

It also indicates the solidarity per inhabitant, measured by calculating the difference between the total amounts per capita each Land would receive in case of the application of an allocation key based on the index before funding and the amounts actually received. 


\section{Al Macrothink}

Research in Applied Economics

ISSN 1948-5433

2014, Vol. 6, No. 2

Table 6. Changes in the financial position of Länder before and after the introduction of different funding mechanisms (2010)

\begin{tabular}{|c|c|c|c|c|c|c|c|c|c|c|c|c|}
\hline Land & $\begin{array}{c}\text { Personal } \\
\text { income tax } \\
\text { (PIT), } \\
\text { corporate tax } \\
\text { (CT) and } \\
\text { Länder tax } \\
\text { (LT) } \\
\text { (thousand } \\
\text { euro) } \\
\end{array}$ & $\begin{array}{c}\text { PIT, CT } \\
\text { and LT } \\
\text { index } \\
\end{array}$ & $\begin{array}{c}\text { VAT } \\
\text { (thousand } \\
\text { euro) }\end{array}$ & $\begin{array}{c}\text { Royalties } \\
\text { (thousand } \\
\text { euro) }\end{array}$ & $\begin{array}{c}\text { PIT, CT, } \\
\text { LT, } \\
\text { VAT } \\
\text { and } \\
\text { royalties } \\
\text { index } \\
\end{array}$ & $\begin{array}{c}\text { Equalization } \\
\text { (thousand } \\
\text { euro) }\end{array}$ & $\begin{array}{c}\text { PIT, CT, } \\
\text { LT, VAT, } \\
\text { royalties } \\
\text { and } \\
\text { equalization } \\
\text { index } \\
\end{array}$ & $\begin{array}{c}\text { General } \\
\text { federal } \\
\text { grants } \\
\text { (GFG) } \\
\text { (thousand } \\
\text { euro) } \\
\end{array}$ & $\begin{array}{c}\text { PIT, CT, } \\
\text { LT, VAT, } \\
\text { royalties, } \\
\text { equalization } \\
\text { and GFG } \\
\text { index } \\
\end{array}$ & $\begin{array}{c}\text { Exceptional } \\
\text { federal } \\
\text { grants } \\
\text { (EFG) } \\
\text { (thousand } \\
\text { euro) }\end{array}$ & $\begin{array}{c}\text { PIT, CT, } \\
\text { LT, VAT, } \\
\text { royalties, } \\
\text { equalization, } \\
\text { GFG and } \\
\text { EFG index }\end{array}$ & $\begin{array}{c}\text { Solidarity } \\
\text { per } \\
\text { inhabitant } \\
\text { (euro) }\end{array}$ \\
\hline \multicolumn{13}{|l|}{ North Rhine- } \\
\hline Westphalia & 23488028 & 100.50 & 15393014 & 486 & 94.59 & 354301 & 95.46 & 118549 & 94.43 & 0 & 89.61 & -268 \\
\hline Bavaria & 21197350 & 129.33 & 10795580 & 440 & 110.98 & -3511134 & 98.80 & 0 & 97.45 & 0 & 92.47 & -907 \\
\hline \multicolumn{13}{|l|}{ Baden- } \\
\hline $\begin{array}{l}\text { Württemberg } \\
\text { Lower }\end{array}$ & 16495969 & 117.21 & 9269946 & 320 & 104.09 & -1708837 & 97.19 & 0 & 95.85 & 0 & 90.96 & -646 \\
\hline Saxony & 8898695 & 85.69 & 8197886 & 531652 & 96.51 & 259089 & 97.93 & 127487 & 97.27 & 0 & 92.31 & 163 \\
\hline Hesse & 10114447 & 127.40 & 5229050 & 629 & 109.89 & -1752340 & 97.34 & 0 & 96.00 & 0 & 91.11 & -893 \\
\hline Saxony & 2737375 & 50.34 & 6118901 & 1313 & 92.61 & 853882 & 101.54 & 350045 & 103.75 & 2624368 & 124.14 & 1816 \\
\hline \multicolumn{13}{|l|}{ Rhineland- } \\
\hline Palatinate & 5111201 & 97.43 & 3556506 & 3855 & 93.98 & 266630 & 96.87 & 144069 & 97.08 & 46016 & 92.60 & -119 \\
\hline \multicolumn{13}{|l|}{ Saxony- } \\
\hline Anhalt & 1483533 & 48.33 & 3512652 & 152 & 92.54 & 497026 & 101.75 & 202353 & 104.05 & 1615232 & 126.74 & 1929 \\
\hline \multicolumn{13}{|l|}{ Schleswig- } \\
\hline Holstein & 3461707 & 93.39 & 2655049 & 81919 & 95.08 & 101218 & 96.63 & 51431 & 96.08 & 53174 & 91.94 & -36 \\
\hline Thuringia & 1427639 & 48.66 & 3348437 & 1687 & 92.58 & 472220 & 101.73 & 192358 & 104.01 & 1482641 & 125.59 & 1893 \\
\hline Brandenburg & 2030142 & 61.84 & 3335495 & 748 & 92.94 & 401042 & 99.88 & 176056 & 101.52 & 1497835 & 120.62 & 1446 \\
\hline \multicolumn{13}{|l|}{ Mecklenburg- } \\
\hline Vorpommern & 1056519 & 49.01 & 2452764 & 690 & 92.58 & 399149 & 103.11 & 157275 & 105.78 & 1110560 & 127.80 & 1938 \\
\hline Saarland & 1063211 & 79.63 & 1130771 & 0 & 93.43 & 89331 & 97.23 & 46407 & 97.85 & 63400 & 95.38 & 388 \\
\hline Berlin & 3976339 & 88.18 & 3453049 & 0 & 93.67 & 2899964 & 130.24 & 911697 & 139.78 & 1706449 & 152.79 & 1590 \\
\hline Hamburg & 3667583 & 157.45 & 1534200 & 104 & 126.98 & -66307 & 125.36 & 0 & 123.64 & 0 & 117.33 & -987 \\
\hline Bremen & 821046 & 95.08 & 604573 & 0 & 93.87 & 444764 & 123.15 & 146022 & 130.94 & 60332 & 127.98 & 809 \\
\hline Total & 107030784 & 100 & 80587873 & 623995 & 100 & 0 & 100 & 2623750 & 100 & 10260007 & 100 & 0 \\
\hline
\end{tabular}

Sources: Second order of Germany's federal finance Minister with a view to implementing the financial equalization law of 2010, financial equalization law between the federal state and the Länder, own calculations.

As can be seen from e.g. table 6 above, the mechanisms in place are extremely redistributive and lead to an important paradox of revenues. We indeed see large differences between the index before funding based on revenues from personal income tax, corporate tax and Länder tax and the index after funding taking into account, on top of these revenues, the entitlement to VAT shares, royalties, horizontal equalization and general and exceptional federal grants.

Before funding, the indexes range from 48.33 (Saxony-Anhalt) to 157.45 (Hamburg) and after funding, between 89.61 (North Rhine-Westphalia) and 152.79 (Berlin). The greatest gap between Länder falls from 109.12 to 63.18 .

In fact, nine Länder benefit from the solidarity, receiving between 163 and 1938 euro per inhabitant and the other seven finance it, "paying” between 36 and 987 euro per inhabitant.

The ranking of Länder before and after funding, is shown in Table 7 and Chart 1 below. 


\section{Macrothink}

Research in Applied Economics

ISSN 1948-5433

2014, Vol. 6, No. 2

Table 7. Ranking of Länder in terms of wealth index per capita, before and after application of funding mechanisms for Länder (2010)

\begin{tabular}{cccccc}
\hline & Before funding & \multicolumn{3}{c}{ After funding } \\
\hline Position & Land & Index & Position & Land & Index \\
\hline 1 & Hamburg & 157.5 & 1 & $\underline{\text { Berlin }}$ & 152.8 \\
2 & Bavaria & 129.3 & 2 & Bremen & 128.0 \\
3 & Hesse & 127.4 & 3 & Mecklenburg-Vorpommern & 127.8 \\
4 & Baden-Württemberg & 117.2 & 4 & $\underline{\text { Saxony-Anhalt }}$ & 126.7 \\
5 & North Rhine-Westphalia & 100.5 & 5 & $\underline{\text { Thuringia }}$ & 125.6 \\
6 & Rhineland-Palatinate & 97.4 & 6 & Saxony & 124.1 \\
7 & Bremen & 95.1 & 7 & $\underline{\text { Brandenburg }}$ & 120.6 \\
8 & Schleswig-Holstein & 93.4 & 8 & Hamburg & 117.3 \\
9 & Berlin & 88.2 & 9 & Saarland & 95.4 \\
10 & Lower Saxony & 85.7 & 10 & Rhineland-Palatinate & 92.6 \\
11 & Saarland & 79.6 & 11 & Bavaria & 92.5 \\
12 & Brandenburg & 61.8 & 12 & Lower Saxony & 92.3 \\
13 & Saxony & 50.3 & 13 & Schleswig-Holstein & 91.9 \\
14 & Mecklenburg-Vorpommern & 49.0 & 14 & Hesse & 91.1 \\
15 & Thuringia & 48.7 & 15 & Baden-Württemberg & 91.0 \\
16 & Saxony-Anhalt & 48.3 & 16 & North Rhine-Westphalia & 89.6 \\
\hline
\end{tabular}

In Table 7 above, Länder located on the territory of former East Germany are shown in bold and underlined and Berlin is underlined.

Sources: Second order of Germany's federal finance Minister with a view to implementing the financial equalization law of 2010, financial equalization law between the federal state and the Länder, own calculations. 


\section{Macrothink}

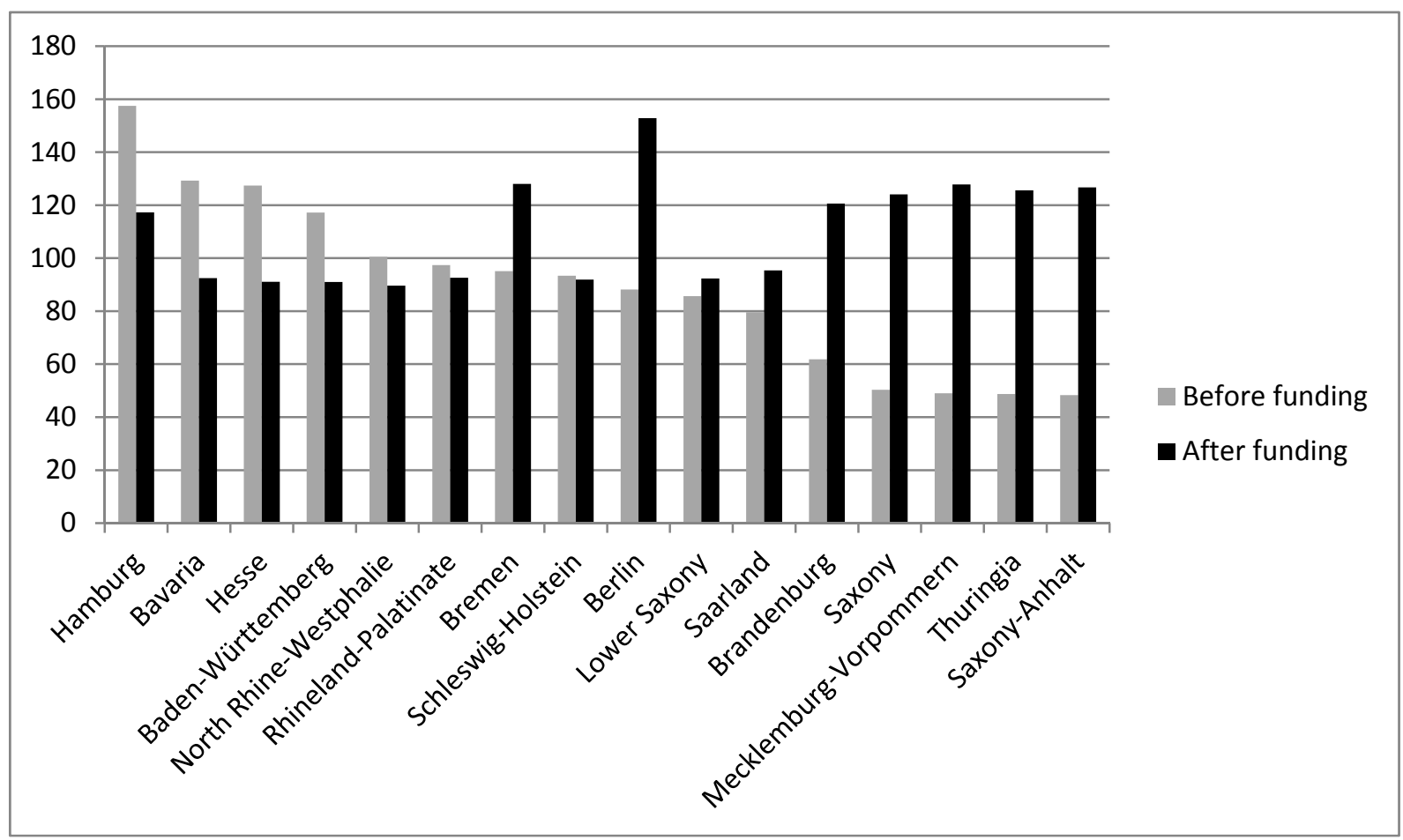

Chart 1. Ranking of Länder in terms of wealth index per capita, before and after application of funding mechanisms for Länder (2010)

Sources: Second order of Germany's federal finance Minister with a view to implementing the financial equalization law of 2010, financial equalization law between the federal state and the Länder, own calculations.

Changes in the ranking of Länder before and after funding allow us to draw a conclusion on the presence of a paradox of revenues, in addition to solidarity.

The Länder all move in the ranking, but some experience a much larger change in relative position than others. Hesse and Baden-Württemberg has both fallen eleven places, going from the third to the fourteenth position and from the fourth to the fifteenth position respectively. By contrast, Saxony-Anhalt has gained twelve places, going from the sixteenth to the fourth position, and Mecklenburg-Vorpommern has climbed eleven places, moving to the third position after funding.

Also interesting to note is that the major beneficiaries of the funding are Länder located on the territory of the former GDR, which are bottom of the league $\left(12^{\text {th }}, 13^{\text {th }}, 14^{\text {th }}, 15^{\text {th }}\right.$ and $16^{\text {th }}$ position) before funding and rank number 3, 4, 5, 6 and 7 after funding. The same applies to Berlin (city-state that used to be divided into East [GDR] and West Berlin [FRG]), which moves from the $9^{\text {th }}$ to the $1^{\text {st }}$ position after funding. The progression of Eastern Länder and of Berlin is mainly due to the exceptional federal grants, one of the aims of which is to compensate for the backwardness with regard to infrastructures and for the low financial strength of municipalities in the five eastern Länder and in the city-state of Berlin. 


\section{Conclusion}

A reform of the financing of German Länder occurred in 2001 and came into force in 2005.

The aim of this paper was to explain the funding mechanisms of Länder and to measure to what extent they generate solidarity and have an influence on the wealth of Länder.

Our analysis has highlighted a very redistributive system, particularly generous to the Länder located in former East Germany, which leads to an important paradox of revenues.

This paradox of revenues may be legitimate in order to relaunch the economy in the poorest Länder. Furthermore, this situation is not an isolated case. A paradox of revenues was for instance observed in Belgium (Pagano, Vandernoot \& Tyrant, 2011) and in Spain (Bellanca, Martinez Sans \& Vandernoot, 2013).

Further research could be conducted to study the financial flows between Länder on longer periods in order to measure the cumulative extent of the phenomenon.

\section{References}

Bellanca, S., Martinez Sans M., \& Vandernoot J. (2013). The solidarity in the Spanish funding of autonomous communities. International Business Research, 6(5), 45-54. http://dx.doi.org/10.5539/ibr.v6n5p45

Bundesministerium der Finanzen (2012). Der Bundesstaatliche Finanzausgleich. Retrieved from

http://www.bundesfinanzministerium.de/Content/DE/Standardartikel/Themen/Oeffentlic he_Finanzen/Foederale_Finanzbeziehungen/Laenderfinanzausgleich/BFAG.pdf?_blob $=$ publicationFile $\& v=2$

Deutsche Press Agentur (2013, March 26). Karlsruhe prüft Finanzausgleich für Länder. Badische Zeitung. Retrieved from http://www.badische-zeitung.de/deutschland-1/karlsruhe-prueft-finanzausgleich-fuer-lae nder--70338955.html

Frémy, D., \& Frémy, M. (2003). Quid 2004. Paris, France. Editions Robert Laffont.

Funk, A. (2013, February 4). Bayern und Hessen wollen in Karlsruhe klagen. Der Tagesspiegel. Retrieved from http://www.tagesspiegel.de/politik/laenderfinanzausgleich-bayern-und-hessen-wollen-in -karlsruhe-klagen/7728906.html

Gesetz über den Finanzausgleich zwischen Bund und Ländern (Germany) Retrieved from https://www.bundesfinanzministerium.de/Content/DE/Standardartikel/Themen/Oeffentli che_Finanzen/Foederale_Finanzbeziehungen/Laenderfinanzausgleich/Finanzausgleichge setz-15.7.2013.pdf?_blob=publicationFile\&v=1

Grundgesetz für die Bundesrepublik Deutschland (Germany). Retrieved from http://www.gesetze-im-internet.de/bundesrecht/gg/gesamt.pdf 
Gunlicks, A. (2003). The Länder and German federalism.Manchester, Manchester University Press. http://dx.doi.org/10.7228/manchester/9780719065323.001.0001

Pagano, G., Vandernoot, J., \& Tyrant, T. (2011). Vingt ans de solidarité entre les entités fédérées (1989-2009). Courrier hebdomadaire du CRISP, 2122, 1-39. http://dx.doi.org/10.3917/cris.2122.0005

Spahn, P. B., \& Werner, J. (2007). Germany at the junction between solidarity and subsidiarity. In Bird, R. \& Ebel, R. D. (Eds.), Fiscal fragmentation in decentralized countries: Subsidiarity, solidarity and asymmetry (pp. 89-113). Cheltenham, United Kingdom, Edward Elgar Publishing.

Zweite Verordnung zur Durchführung des Finanzausgleichsgesetzes im Ausgleichsjahr 2010 (Germany). Retrieved from http://www.bundesfinanzministerium.de/Content/DE/Standardartikel/Themen/Oeffentlic he_Finanzen/Foederale_Finanzbeziehungen/Laenderfinanzausgleich/laenderfinanzausgl eich-anlage08.pdf?_blob=publicationFile \&v=2

\section{Notes}

Note 1. Frémy D. and Frémy M., Quid 2004, 2004.

Note 2. Baden-Württemberg, Bavaria, Bremen, Hamburg, Hesse, Lower Saxony, North Rhine-Westphalia, Rhineland-Palatinate, Saarland and Schleswig-Holstein.

Note 3. Brandenburg, Mecklenburg-Vorpommern, Saxony, Saxony-Anhalt and Thuringia.

Note 4. Bundesverfassungsgericht, 2 BvF 2/98 of November 11, 1999.

Note 5. Gesetz über den Finanzausgleich zwischen Bund und Ländern (Finanzausgleichsgesetz-fag), December 20, 2001.

Note 6.

http://www.badische-zeitung.de/deutschland-1/karlsruhe-prueft-finanzausgleich-fuer-laender-70338955.html

http://www.tagesspiegel.de/politik/laenderfinanzausgleich-bayern-und-hessen-wollen-in-karls ruhe-klagen/7728906.html

Note 7. Bundesministerium der Finanzen, Der Bundesstaatliche Finanzausgleich, 7 pages, 2012.

Note 8. Zweite Verordnung zur Durchführung des Finanzausgleichsgesetzes im Ausgleichsjahr 2010, 16/09/2011, calculs propres.

Note 9. Zweite Verordnung zur Durchführung des Finanzausgleichsgesetzes im Ausgleichsjahr 2010.

Note 10. Grundgesetz für die Bundesrepublik Deutschland, amended version of July 11, 
2012.

Note 11. This coefficient stands at 1.35 for the three city-states (Berlin, Bremen and Hamburg) since they have higher needs per inhabitant due to their dual status. All the other Länder have a coefficient of 1 . Source: Bundesministerium der Finanzen, Finanzausgleichsgesetz, op. cit.

Note 12. Source: own calculations.

Note 13. This coefficient stands at 1.35 for the three city-states (Berlin, Bremen and Hamburg) since they have higher needs per inhabitant due to their dual status. The Länder of Mecklenburg-Vorpommern, Brandenburg and Saxony-Anhalt benefit from a coefficient of 1.05, 1.03 and 1.02 respectively, due to their low population density. All the other Länder have a coefficient of 1 . Source: Bundesministerium der Finanzen, Finanzausgleichsgesetz, op. cit.

Note 14. Source: own calculations.

Note 15. Financial equalization law between the federal state and the Länder (Finanzausgleichsgesetz)

\section{Copyright Disclaimer}

Copyright reserved by the author(s).

This article is an open-access article distributed under the terms and conditions of the Creative Commons Attribution license (http://creativecommons.org/licenses/by/3.0/). 